\title{
TECTONIC SHIFT MEASUREMENT WITH GEODETIC SAR PROCESSING
}

Hartmut Runge, Ulrich Balss, Steffen Suchandt, Michael Eineder

DLR, German Aerospace Center, Institute of Remote Sensing Technology, 82234 Wessling, Germany

Introduction

A new method for precise, high-resolution and large-scale measurement of plate tectonics with the aid of radar remote sensing. For the derivation of the 3D vectors of

tectonic displacements two measurement intervals, separated by at least one year or by a tectonic event are required. At each interval several satellite images from

different Radar viewing angles are obtained, and the 3D-coordinates of ground control points (GCPs) are calculated.

SAR Geodesy

By correcting the influence of the ionosphere, atmosphere and earth tides, it is possible to measure the absolute coordinates of ground control points with high accuracy.

By comparing the absolute positions of the GCPs of the two acquisition periods, the displacements that have occurred in the meantime can be determined in $X$, $Y$ and $Z$.

Applications

Measurement of continental drift, of elevations and subsidence by the melting of very large glacier areas or in gas production, as well as of tectonic shifts after earthquakes

Furthermore, the continuity of continental drift in earthquake-prone areas can be checked with the help of long-term recording series.

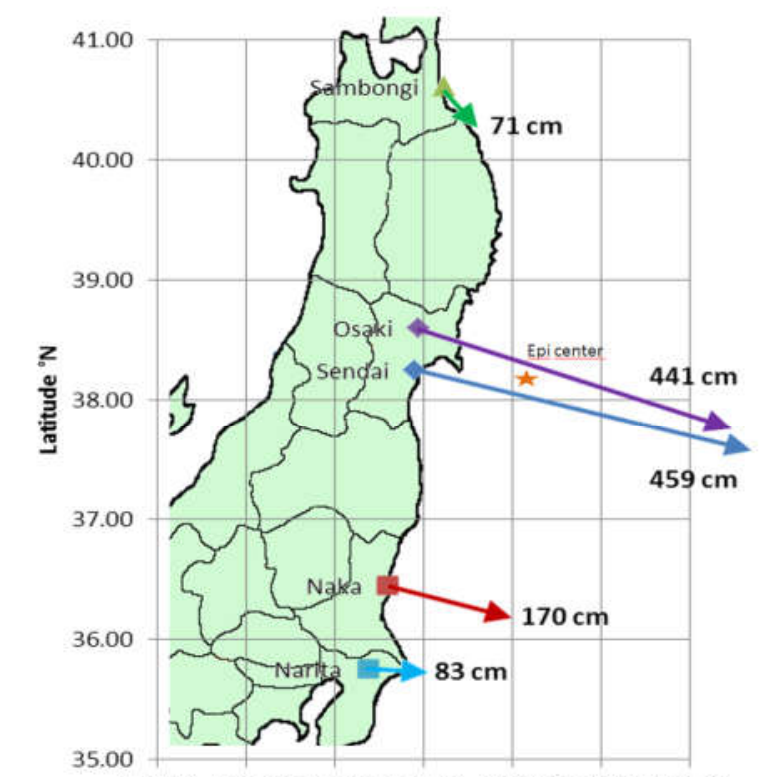

\section{Radar Measurement Of The \\ Tectonic Shift Of The Honshu Island (Japan) During The Last Decade}

- Mainly caused by the Tōhoku earthquake in March 2011

- Obtained with TerraSAR-X SpotLight Mode Data

- Method:

Measurement of the absolute geodetic coordinates of Radar point targets like lamp poles and corners of buildings at two different times (before and after the event).

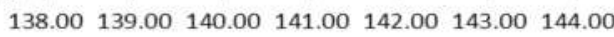

Lonitude ${ }^{\circ} \mathrm{E}$

Numeric Results From TerraSAR-X Of The Honshu Tectonic Shifts

\begin{tabular}{|c|c|c|c|c|c|}
\hline Site & $\begin{array}{c}\text { Time } \\
\text { Interval }\end{array}$ & $\begin{array}{c}\text { Number of } \\
\text { GCPs } \\
\text { used }\end{array}$ & $\begin{array}{l}\text { Shift } \\
\text { South } \\
{[\mathrm{cm}]}\end{array}$ & $\begin{array}{l}\text { Shift } \\
\text { East } \\
\text { [cm] }\end{array}$ & $\begin{array}{l}\text { Elevation or } \\
\text { Subsidence } \\
\text { [cm] }\end{array}$ \\
\hline Sambongi & $2010 / 2011$ & $\begin{array}{c}277 \\
\text { (better } 20 \mathrm{~cm} \text { ) }\end{array}$ & $\begin{array}{c}55 \\
+1-4\end{array}$ & $\begin{array}{c}45 \\
+/-6\end{array}$ & $\begin{array}{l}\text { Subsidence: } \\
4+/-4\end{array}$ \\
\hline Osaki & 2009 / 2018 & $\begin{array}{c}49 \\
\text { (better } 20 \mathrm{~cm} \text { ) }\end{array}$ & $\begin{array}{l}149 \\
+/-9\end{array}$ & $\begin{array}{c}415 \\
+/-17\end{array}$ & $\begin{array}{l}\text { Elevation: } \\
\mathbf{3}+/-17\end{array}$ \\
\hline Sendai & $2008 / 2018$ & $\begin{array}{c}117 \\
\text { (better } 20 \mathrm{~cm} \text { ) }\end{array}$ & $\begin{array}{l}121 \\
+/-8\end{array}$ & $\begin{array}{l}443 \\
+/-9\end{array}$ & $\begin{array}{c}\text { Elevation: } \\
6+1-7\end{array}$ \\
\hline Naka & $2008 / 2018$ & $\begin{array}{c}66 \\
\text { (better } 30 \mathrm{~cm} \text { ) }\end{array}$ & $\begin{array}{c}47 \\
+/-10\end{array}$ & $\begin{array}{c}163 \\
+/-18\end{array}$ & $\begin{array}{l}\text { Subsidence: } \\
\mathbf{2 1}+/-17\end{array}$ \\
\hline Narita & 2009 / 2011 & $\begin{array}{c}66 \\
\text { (better } 30 \mathrm{~cm} \text { ) }\end{array}$ & $\begin{array}{c}6 \\
+/-12\end{array}$ & $\begin{array}{c}83 \\
+/-15\end{array}$ & $\begin{array}{l}\text { Elevation: } \\
24+/-19\end{array}$ \\
\hline
\end{tabular}

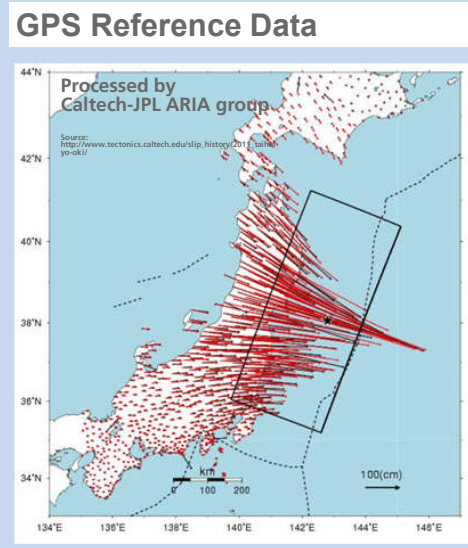

\section{Conclusions:}

- Geodetic SAR is a valuable tool to measure tectonic displacements in 3D-coordinates

- It works best over sites with a lot of man-made infrastructure, like buildings and lamp poles

- The achieved accuracy over cities is better than $10 \mathrm{~cm}$ in $X, Y$ and $Z$

- Remote Sensing Method! No installations on the ground are required 